\title{
ANALISIS YURIDIS DASAR PERTIMBANGAN KEBIJAKAN LOCKDOWN PADA SITUASI DARURAT KESEHATAN DI TINGKAT DAERAH
}

\author{
Ardhiwinda Kusumaputra* dan Endang Retnowati \\ Fakultas Hukum Universitas Wijaya Kusuma Surabaya \\ J1. Dukuh Kupang XXV - 54, Surabaya 60225 \\ ardhiputra82@gmail.com
}

\begin{abstract}
Indonesia is a country with regions that have autonomy rights. Through the Act No. 23 of 2014 concerning Regional Government, a division of functions is arranged between the Central Government and Regional Governments. However, the regulation of the division of functions does not always guarantee legal certainty, especially in dealing with health emergencies, such as the corona virus outbreak. It is possible to have a conflict of authority that occurs in creating policies, especially in the creating of a lockdown policy for a particular region. This paper raises two basic problems: First, what is the fundamental basis for a lockdown policy on health emergencies? Second, does the local government establish a lockdown policy for health emergencies that occur in the regions? This paper recommends the need for further construction related to the role of the Regional Government in this matter.
\end{abstract}

Keyword: Lockdown Policy; Health Emergencies; Regional Government

\begin{abstract}
Abstrak
Indonesia merupakan negara yang memberlakukan hak otonomi di daerah. Melalui adanya Undang-Undang Nomor 23 Tahun 2014 tentang Pemerintahan Daerah, diatur pembagian urusan antara Pemerintah Pusat dan Pemerintah Daerah. Namun, pengaturan atas pembagian urusan tersebut tidaklah selalu menjamin kepastian hukum, khususnya dalam menangani situasi darurat kesehatan, seperti wabah virus corona. Tidak menutup kemungkinan adanya konflik kewenangan yang terjadi berkaitan dengan penyusunan kebijakan, khususnya pada pembentukan kebijakan lockdown atas suatu daerah tertentu. Dalam penulisan ini akan dibahas: Pertama, apa yang menjadi dasar fundamental adanya kebijakan lockdown atas situasi darurat kesehatan? Kedua, apakah pemerintah daerah dapat menetapkan kebijakan lockdown atas situasi darurat kesehatan yang terjadi di daerah? Tulisan ini merekomendasikan perlunya konstruksi lebih lanjut terkait peran Pemerintah Daerah dalam hal tersebut.
\end{abstract}

Kata Kunci: Kebijakan Lockdown; Darurat Kesehatan; Pemerintah Daerah

\section{A. Pendahuluan}

Pada dasarnya, negara merupakan integrasi dari kekuasaan politik. Negara merupakan alat dari masyarakat yang mempunyai kekuasaan untuk mengatur hubungan-hubungan manusia dalam masyarakat dan menertibkan gejala-gejala kekuasaan dalam masyarakat (Budiardjo,
2008). Negara mempunyai wilayah permanen dan menguasai atas wilayah serta apa yang ada di dalamnya. Kekuasaan yang dimiliki oleh negara, dijalankan oleh pemerintah, dengan didasarkan pada suatu sistem pemerintahan. Artinya, Pemerintah bertindak untuk dan atas nama negara, guna mencapai tujuan negara. Berdasar pada konstitusi Undang-Undang Dasar Negara 
Republik Indonesia Tahun 1945 (selanjutnya disebut sebagai UUD NRI 1945), salah satu tujuan negara adalah untuk melindungi segenap bangsa Indonesia. Hal itu tentunya termasuk dalam hak-hak dasar bagi warganya.

Guna pencapaian tujuan tersebut, maka pelaksanaan pemerintahan dilakukan dengan desentralisasi dan otonomi, dalam kerangka Negara Kesatuan Republik Indonesia. Pelaksanaan desentralisasi dan otonomi, sebagaimana diatur berdasarkan Pasal 18 UUD NRI 1945, memberikan kebebasan kepada daerah untuk dapat mengatur dan mengurus sendiri urusan rumah tangga daerahnya. Namun, kebebasan tersebut tidak bermakna merdeka sepenuhnya. Pelaksanaannya tetap memperhatikan dan tidak boleh bertentangan dengan aturan yang ditetapkan oleh pemerintah pusat (Pangerang \& Pradana;, 2018). Salah satu bentuk tindak lanjut adanya otonomi daerah, termasuk pada tingkat Kabupaten/Kota, telah diundangkan Undang-Undang Nomor 23 Tahun 2014 tentang Pemerintahan Daerah (selanjutnya disebut UU No. 23 Tahun 2014). Berdasar pada UU No. 23 Tahun 2014, telah diatur pembagian urusan kewenangan antara pemerintah pusat dan daerah. Hal tersebut sebagaimana ditegaskan pada Pasal 9 dan 10 UU No. 23 Tahun 2014, bahwa urusan pemerintahan terbagi atas urusan pemerintahan absolut, konkuren dan umum.

Sekalipun telah ditetapkan pembagian urusan, tidak menutup kemungkinan masih terdapat konflik kewenangan antara Pemerintah Pusat dengan Pemerintah Daerah. Pada situasi tertentu, yang menghendaki adanya keputusan cepat dan tepat, walaupun seharusnya melalui proses persetujuan Pemerintah Pusat, Pemerintah Daerah sangat mungkin memberikan keputusan. Hal ini dilakukan berdasarkan prinsip otonomi dan dalam bentuk diskresi, tentunya dengan tetap berpegang pada ketentuan peraturan perundang-undangan.

Salah satu situasi darurat yang terjadi adalah darurat kesehatan. Pada tahun 2020, darurat kesehatan menjadi kondisi yang mempengaruhi stabilitas negara Indonesia, khususnya pada daerah-daerah tertentu yang mengharuskan adanya penanganan secara tepat dan cepat. Wabah Virus Covid-19 (dikenal pula sebagai virus corona), telah menginfeksi setidaknya 29.521 orang (per tanggal 1 Juni 2020), dan merenggut 1.770 nyawa di seluruh Indonesia. Dasar hukum yang digunakan untuk menyusun kebijakan penanganan, setidaknya turut pula mendasarkan pada UUD NRI 1945, Undang-Undang Nomor 24 Tahun 2007 tentang Penanggulangan Bencana (selanjutnya disebut UU No. 24 Tahun 2007) dan Undang-Undang Nomor 6 Tahun 2018 tentang Kekarantinaan Kesehatan (selanjutnya disebut UU No. 6 Tahun 2018).

Apabila ditelaah, antara UU No. 24 Tahun 2007, UU No. 6 Tahun 2018, dan UU No. 23 Tahun 2014, memang dapat berpotensi menimbulkan adanya konflik apabila tidak dipahami secara tepat. Pemerintah Daerah, atas dasar otonomi mempunyai hak untuk mengurus urusan daerahnya, termasuk dalam menangani persoalan yang ikut terjadi di daerah, dengan juga didasarkan pada UU No. 23 Tahun 2014. Berbeda dengan tatanan yang diatur berdasar pada UU No. 24 Tahun 2007, penanganan atas situasi darurat dilakukan secara khusus oleh Badan Nasional Penanggulangan Bencana (BNPB), dan Badan Penanggulangan Bencana Daerah (BPBD). Ditegaskan pula pada Pasal 1 angka 3 UU No. 24 Tahun 2007, bahwa wabah penyakit masuk sebagai kategori bencana non-alam. Secara lebih khusus, berkaitan dengan bencana non-alam yaitu wabah penyakit, turut diatur dalam UU No. 6 Tahun 2018. Mencermati materi muatan dalam UU No. 6 Tahun 2018, ternyata tidak menyebut peran dari BNPB maupun BPBD. Padahal kategori persoalannya seharusnya masuk dalam penanganan BNPB maupun BPBD. Berdasar Pasal 4 UU No. 6 Tahun 2018, Pemerintah Pusat dan Pemerintah Daerah mempunyai tanggung jawab untuk melindungi masyarakat dari darurat wabah penyakit. Bahkan, berdasar pada Pasal 5 UU No. 6 Tahun 2018 Pemerintah Pusat, 
bersama dengan Pemerintah Daerah juga bertanggung jawab untuk menyelenggarakan kekarantinaan kesehatan. Berdasar pada regulasi ini, maka Pemerintah Daerah pada dasarnya juga mempunyai kewenangan untuk melakukan penanganan darurat kesehatan.

Penetapan kebijakan "lockdown" pada daerah tertentu, termasuk tingkat Kabupaten/Kota idealnya harus disusun secara terpadu dan tepat sasaran. Diikuti dengan langkah implementasi yang efektif. Kebijakan lockdown merupakan upaya penutupan wilayah guna mencegah penyebaran wabah penyakit yang terjadi. Secara yuridis, kebijakan "lockdown" dapat disebut sebagai karantina wilayah, yang diikuti dengan adanya Pembatasan Sosial Berskala Besar (PSBB). Perlu kiranya untuk dikaji secara komprehensif berkaitan dengan kewenangan Pemerintah Daerah untuk menetapkan kebijakan "lockdown", tanpa harus melalui persetujuan Pemerintah Pusat.

Apabila mencermati pada peraturan perundang-undangan yang ada, memang belum ditemukan rumusan yang secara tegas menyatakan bahwa Pemerintah Daerah dapat menetapkan kebijakan lockdown atas darurat kesehatan tanpa persetujuan Pemerintah Pusat. Kondisi demikian ini tentu menjadi problematika hukum secara normatif, khususnya berkaitan dengan ketidaklengkapan norma. Padahal situasi darurat kesehatan sangat mungkin terjadi hanya di suatu daerah tertentu, dan membutuhkan penanganan cepat dari Pemerintah Daerahnya. Namun, regulasi yang ada masih mengarahkan pada tindakan prosedural Pemerintah Pusat, khususnya jika hendak memberlakukan lockdown. Hal ini dibuktikan dengan beberapa peraturan yang ada dalam menghadapi darurat kesehatan (wabah Virus COVID-19), yang dikeluarkan oleh Pemerintah Pusat, antara lain: a) Keputusan Presiden Republik Indonesia Nomor 7 Tahun 2020 tentang Gugus Tugas Percepatan Penanganan Corona Virus Disease 2019 (COVID-19); b) Surat Edaran HK.02.01/MENKES/202/2020 tentang Protokol Isolasi Diri Sendiri dalam
Penanganan Corona Virus Disease (COVID19); c) Peraturan Pemerintah Nomor 21 Tahun 2020 tentang Pembatasan Sosial Berskala Besar Dalam Rangka Percepatan Penanganan Covid-19; d) Keputusan Presiden Nomor 11 Tahun 2020 tentang Penetapan Status Kedaruratan Kesehatan Masyarakat; e) Keputusan Presiden Nomor 12 tahun 2020 tentang Penetapan Bencana non-alam Penyebaran Covid-19 sebagai Bencana Nasional.

Selama ini, kebijakan tersebut menjadi acuan bagi pemerintah daerah dalam menyusun kebijakannya. Artinya, Pemerintah Daerah masih harus menunggu keputusan dari Pemerintah Pusat atas situasi darurat kesehatan, baru kemudian Pemerintah Daerah dapat menentukan sikapnya. Pada tingkat daerah, misalnya di Jawa Timur, turut ditindaklanjuti dengan adanya Surat Edaran Gubernur Jawa Timur Nomor 420/1780/101.1/2020 tentang Peningkatan Kewaspadaan terhadap Corona Virus Disease 2019 (COVID-19) di Jawa Timur; Keputusan Gubernur Jawa Timur Nomor 188/202/KPTS/013/2020 tentang Pemberlakuan Pembatasan Sosial Berskala Besar Dalam Penanganan Corona Virus Disease 2019 (Covid-19) di Wilayah Kota Surabaya, Kabupaten Sidoarjo, dan Kabupaten Gresik. Memang, apabila melihat secara substansi dari produk hukum tersebut, kurang mempunyai kekuatan mengikat, dan tidak ada akibat hukumnya (Baihaki, 2020).

Hal ini tentu justru dapat menghambat penyelesaian darurat kesehatan yang terjadi, sebab hanya berpaku pada legal proseduralnya. Padahal penanganan atas situasi darurat kesehatan membutuhkan langkah yang cepat dan efisien, agar tidak terjadi penyebaran wabah penyakit. Pada kondisi ini, eksistensi hukum harus mampu menjawab dan mengatasi persoalan, bukan justru menjadi penghambat. Apalagi jika mengingat bahwa darurat kesehatan menghendaki adanya kebijakan lockdown (karantina wilayah), dengan maksud agar wabah tidak menyebar ke daerah-daerah lain. Diperlukan adanya penyusunan kebijakan yang proporsional, dengan 
memperhatikan pada beberapa aspek yang sifatnya fundamental.

Kebijakan tersebut juga mempunyai dampak lanjutan, khususnya terhadap hak masyarakat dalam beraktifitas. Hal tersebut mengingat bahwa keadaan bahaya dibangun atas dasar dikotomi buatan antara norma (norm) dan pengecualian (exception). Kondisi keadaan bahaya, yang melahirkan kebijakan lockdown, dapat menjadi legitimasi pembatasan hak oleh Pemerintah (Sheeran, 2013). Jangan sampai kebijakan lockdown yang ditetapkan, justru menjadi alat bagi Pemerintah untuk mencederai warga masyarakatnya. Oleh karena itu, menjadi aspek yang penting untuk dikaji berkaitan dengan dua rumusan problematika dasar. Pertama, apa yang menjadi dasar fundamental adanya kebijakan lockdown atas situasi darurat kesehatan? Kedua, apakah Pemerintah Daerah dapat menetapkan kebijakan lockdown atas situasi darurat kesehatan yang terjadi di daerah tanpa penetapan Pemerintah Pusat?

\section{B. Pembahasan}

\section{Dasar Fundamental Kebijakan Lockdown pada Suatu Daerah atas Situasi Darurat Kesehatan}

Secara mendasar, dalam lingkup negara kesejahteraan (wefare state), tugas pemerintah tidak hanya sebatas untuk melaksanakan undang-undang. Pemerintah turut mempunyai kewajiban untuk menyelenggarakan kepentingan umum (bestuurzor), atau mengupayakan kesejahteraan sosial. Konsekuensinya, maka pemerintah diberi kewenangan untuk campur tangan (staatsbemoeienis) dalam kehidupan masyarakat, dengan batas-batas yang sudah diperkenankan oleh hukum (HR, 2010). Bersamaan dengan adanya kewenangan tersebut, maka pemerintah dapat menyusun, menggunakan dan melaksanakan peraturan perundangundangan.

Berdasar pada kewenangan yang dimiliki itu pula, maka ketika negara menghadapi situasi darurat (state of emergency), dapat segera mengambil langkah untuk melindungi kepentingan masyarakat. Hal ini tidak dapat dilepaskan dari pemahaman bahwa negara tidak selalu dalam kondisi normal. Terdapat potensi yang mengancam stabilitas negara, baik karena faktor eksternal maupun internal. Secara teoritis, setidaknya terdapat tiga unsur penting yang secara bersama-sama membentuk pengertian keadaan bahaya yang menimbulkan kegentingan yang memaksa, yaitu (Asshiddiqie, 2007): a) Unsur ancaman yang membahayakan (dangerous threat); b) Unsur kebutuhan yang mengharuskan (reasonable necessity); dan c) Unsur keterbatasan waktu (limited time).

Kondisi demikian itu, mempunyai relevansi konstitusional dengan Pasal 12 dan 22 UUD NRI 1945. Apabila menelaah peraturan perundang-undangan yang berlaku, berkenaan dengan situasi darurat, maka setidaknya terdapat beberapa kondisi darurat yang mungkin terjadi di Indonesia, yaitu Darurat Sipil, Darurat Militer, Darurat Perang, Darurat Bencana (terbagi dalam Bencana alam, non-alam dan sosial), dan Darurat Kesehatan.

Menelusuri aspek historis tentang keadaan darurat yang pernah terjadi di Indonesia, salah satunya adalah keadaan darurat militer pada tahun 1965-1966. Saat itu terjadi gerakan G30S/PKI, yang kemudian ditindaklanjuti dengan ditetapkannya Surat Perintah 11 Maret (Supersemar). Presiden pada waktu itu memang tidak mengumuman terjadinya situasi darurat, tapi suasana yang terjadi menunjukkan adanya kondisi darurat (Asshiddiqie, 2007). Hal itu juga ditandai dengan adanya penegasan dari Presiden sebagai Panglima Tertinggi Angkatan Perang.

Saat ini, ketika negara mengalami situasi darurat kesehatan, tentu memerlukan penanganan yang berbeda, khususnya jika ditinjau dari aspek hukum. Pengaturan darurat kesehatan, tidak dapat dipersamakan dengan situasi darurat militer atau darurat perang, sebagaimana yang diatur dalam Peraturan Pemerintah Pengganti Undang- 
Undang Nomor 23 Tahun 1959 tentang Keadaan Bahaya. Eksistensi UU No. 24 Tahun 2007 dan UU No. 6 Tahun 2018, dapat menjadi rujukan dalam menghadapi situasi darurat kesehatan.

Perlu kiranya terlebih dahulu dipahami berkaitan dengan konstruksi dasar hakikat munculnya situasi darurat. Berdasar pada Pasal 12 dan Pasal 22 UUD NRI 1945, kewenangan dasar tetap melekat pada Presiden. Meskipun secara mendasar terdapat juga perbedaan karakteristik penerapan Pasal 12 dan Pasal 22 UUD NRI 1945, utamanya sejak adanya Putusan Mahkamah Konsitusi (Simamora, 2010). Kondisi demikian itu juga mempunyai korelasi dengan Pasal 4 ayat (1) UUD NRI 1945, yaitu Presiden memegang kekuasaan Pemerintahan menurut Undang-Undang Dasar. Pasal 4 ayat (1) UUD NRI 1945, itu juga yang menjadi dasar dalam penyelenggaraan pemerintahan daerah. Artinya, apabila Presiden belum menetapkan adanya situasi yang dianggap darurat, maka kondisi negara masih dalam keadaan normal. Apabila situasi darurat telah diumumkan oleh Presiden, maka barulah diikuti dengan berbagai peraturan yang bersifat pelaksana (Nuh, 2011).

Pernyataan Presiden untuk mengumumkan adanya situasi darurat, juga tidak sembarangan dilakukan. Tetap diperlukan adanya pertimbangan yang komprehensif, sehingga keputusan yang diambil tidak menimbulkan keresahan dan dampak lanjutan yang merugikan. Apabila merujuk pada Pasal 1 angka 19 UU No. 24 Tahun 2007, maka salah satu pemberi rekomendasi atas status darurat bencana kepada Presiden adalah BNPB. Hal ini juga tidak lepas dari peran dan fungsi dari BNPB sebagaimana ditetapkan dalam Pasal $12 \mathrm{UU}$ No. 24 Tahun 2007. Apabila situasi darurat telah ditetapkan, maka sangat mungkin untuk dilakukan penyimpangan hukum dari keadaan normalnya (Adhari, 2019).

Jika ditinjau dari perspektif hukum administrasi negara, tindakan pemerintah tersebut, dengan membentuk peraturan kebijaksanaan, tidak dapat dilepaskan dari kewenangan bebas (vrijbevoegdheid) atau sering juga disebut sebagai freiss ermessen. Pembentukkannya dimaksudkan sebagai wujud efektifitas dalam mencapai suatu tujuan sosial (kepentingan umum dan kesejahteraan sosial) (Mahfud, 1987). Ada beberapa hal yang harus diperhatikan dalam penyusunan freiss ermessen. Menurut Sjachran Basah (Basah, 1992), setidaknya terdapat empat hal, antara lain: a) Ditujukan untuk menjalankan tugas-tugas pelayanan publik (berorientasi pada kepentingan umum); b) Dimungkinkan oleh hukum; c) Dimaksudkan untuk menyelesaikan persoalan penting yang timbul secara tibatiba; d) Dapat dipertanggungjawabkan baik secara moral kepada Tuhan Yang Maha Esa, maupun secara hukum.

Ketika freiss ermessen tersebut dituangkan dalam suatu instrumen yuridis yang tertulis, maka jadilah sebagai peraturan kebijaksanaan. Kewenangan pembentukannya menjadi satu bagian yang melekat pada pemerintahan (inherent aan het bestuur) (HR, 2010). Ada berbagai bentuk peraturan kebijaksanaan yang sering kali dikeluarkan oleh pemerintah, seperti beleidslijnen (garis-garis kebijaksanaan), het beleid (kebijaksanaan), voorschriften (peraturan-peraturan), richlinen (pedomanpedoman), aanschrijvingen (instruksiinstruksi), reglemen (ministriele) (peraturanperaturan menteri), beschikkingen (keputusan-keputusan), en bekenmakingen (pengumuman-pengumuman) (HR, 2010). Menurut Philipus M. Hadjon (Hadjon, 2005), peraturan kebijaksanaan merupakan produk dari perbuatan tata usaha negara. Peraturan ini juga dapat dipahami sebagai suatu peraturan bayangan, atau peraturan semu (psudo-wetgeving). Hal ini menjadikan adanya akibat hukum yang bersifat anomali.

Dapat dipahami bahwa pernyataan presiden untuk mengumumkan adanya situasi darurat, merupakan bagian dari implementasi diskresi. Diikuti dengan pembentukan berbagai peraturan yang mempunyai sifat pelaksana. Peraturan kebijakan yang memuat pembatasan akses suatu wilayah (lockdown), merupakan salah 
satu bentuk tindak lanjut atas pernyataan presiden tentang situasi darurat. Peraturan yang ditetapkan saat dan mendasarkan pada situasi darurat, merupakan perturan luar biasa. Materi muatannya sangat dimungkinkan mengatur hal-hal yang menyimpang dari ketentuan hukum yang berlaku pada saat situasi normal (Nuh, 2011).

Diperbolehkan bagi suatu negara atau wilayah menutup akses bagi warganya untuk keluar masuk wilayah tersebut, serta melarang adanya orang dari luar untuk masuk ke negara atau wilayah tersebut. UU No. 6 Tahun 2018, juga telah mengatur perihal karantina wilayah jika terjadi situasi wabah penyakit. Mengingat dampak yang ditimbulkan apabila dilakukan suatu karantina wilayah (lockdown), khususnya terhadap hak asasi manusia, maka dalam perumusan dan pelaksanaannya haruslah dilakukan secara efektif dan efisien. Tidak dapat dipungkiri jika masih dimungkinkan adanya kelonggaran dalam pelaksanaan karantina wilayah (Amaluddin, 2020).

Perlu juga dipahami bahwa, kebijakan lockdown atas suatu negara atau wilayah diambil dengan dasar kajian yang komprehensif. Merujuk pula pada dasar pembentukan peraturan kebijakan, sebagaimana yang diuraikan oleh Indroharto (HR, 2010), bahwa terdapat beberapa hal yang harus diperhatikan, antara lain: a) Tidak boleh bertentangan dengan peraturan dasar yang mengandung wewenang diskresioner yang dijabarkan; b) Tidak boleh bertentangan dengan nalar yang sehat; c) Harus dipersiapkan dengan cermat, semua kepentingan, keadaan serta alternatifalternatif yang ada perlu dipertimbangkan; d) Isi dari kebijaksanaan harus memberikan kejelasan yang cukup mengenai hak-hak dan kewajiban-kewajiban dari warga yang terkena peraturan tersebut; e) Tujuan dan dasar pertimbangan mengenai kebijaksanaan harus jelas; f) Memenuhi syarat kepastian hukum material, artinya hak-hak yang telah diperoleh dari warga masyarakat yang terkena harus dihormati, kemudian juga harapan-harapan warga yang pantas telah ditimbulkan jangan sampai diingkari.

Idealnya, keenam aspek tersebut haruslah dipahami secara kumulatif. Apalagi perspekti diskresi ini mempunyai relevansi substansi dengan penetapan dan pelaksanaan keadaan darurat kesehatan. Setiap peraturan kebijakan yang dibentuk, khususnya peraturan kebijakan tentang lockdown harus memperhatikan keselurahan aspek itu. Mengingat pula bahwa kebijakan lockdown diambil pada situasi darurat, khususnya dalam menghadapi situasi darurat kesehatan, seperti halnya saat terjadi wabah virus Corona.

Berdasar pada Pasal 12 dan Pasal 22 UUD NRI 1945, setidaknya terdapat dua keadaan darurat negara (state of emergency), yaitu keadaan bahaya dan kegentingan yang memaksa. Sebenarnya, kedua hal tersebut memang sama-sama memberi makna keadaan darurat, namun secara substansi mempunyai perbedaan. Keadaan bahaya lebih menekankan pada pengaruh faktor eksternal, di luar negara, sedangkan hal ihwal kegentingan yang memaksa, lebih menitik beratkan pada faktor internal (Nuh, 2011). Lebih lanjut diuraikan pula oleh Jimly Asshiddiqie (Asshiddiqie, 2007), bahwa terdapat tiga unsur penting untuk dapat disebut sebagai keadaan darurat. Pertama, adanya ancaman yang membahayakan baik kepada pemerintahan ataupun warga masyarakatnya. Kedua, kebutuhan yang mengharuskan bahwa situasi perlu untuk diwaspadai. Ketiga, adanya keterbatasan waktu, bahwa keadaan tersebut menghendaki adanya penanganan secepatnya, sebab jika tidak, dapat menimbulkan dampak berantai.

Selain itu, dalam pembentukannya juga tidak boleh mengesampingkan adanya AsasAsas Umum Pemerintahan yang Baik (selanjutnya disebut AUPB). Secara teoritis AUPB (Hamidi, 1999), merupakan nilainilai etik yang hidup dan berkembang dalam lingkungan Hukum Administrasi Negara dan berfungsi sebagai pegangan bagi pejabat administrasi negara dalam menjalankan fungsinya, serta merupakan alat uji bagi 
hakim administrasi dalam menilai tindakan administrasi negara (yang berwujud penetapan/beschikking). Berdasar pada Pasal 10 Undang-Undang Nomor 30 Tahun 2014 tentang Administrasi Pemerintahan (selanjutnya disebut UU No. 30 Tahun 2014), ditegaskan bahwa AUPB meliputi, asas kepastian hukum, kemanfaatan, ketidakberpihakan, kecermatan, tidak menyalahgunakan wewenang, keterbukaan, kepentingan umum, dan pelayanan yang baik. AUPB tersebut dipahami pula sebagai asas yang bersifat kumulatif, harus diterpakan seluruhnya.

Berkaitan dengan kebijakan lockdown pada tingkat daerah (provinsi, kabupaten/kota), memang sangat mungkin dilakukan, khususnya atas situasi darurat kesehatan. Kontruksi penyusunan dan penetepan kebijakan tersebut, haruslah mendasarkan pada pernyataan Presiden dan peraturan perundang-undangan. Artinya, sebelum adanya pernyataan dan keputusan resmi dari Presiden yang mempunyai kekuatan hukum mengikat, maka Pemerintah Daerah tidak boleh menetapkan kebijakan lockdown.

Didasarkan pula pada UU No. 6 Tahun 2018, kebijakan untuk melakukan menetapkan kebijakan karantina wilayah (lockdown), yang dapat diikuti dengan munculnya PSBB, hanya dilakukan apabila terjadi suatu wabah penyakit menular. Menimbulkan lonjakan penderita yang tidak wajar dalam kurun waktu berdekatan. Ditegaskan pada Pasal 1 angka 1, bahwa: "Kekarantinaan Kesehatan adalah upaya mencegah dan menangkal keluar atau masuknya penyakitdan/atau faktor risiko kesehatan masyarakat yang berpotensi menimbulkan kedaruratan kesehatan masyarakat". Pada Pasal 1 angka 10, bahwa: "Karantina Wilayah adalah pembatasan penduduk dalam suatu wilayah termasuk wilayah pintu Masuk beserta isinya yang diduga terinfeksi penyakit dan/atau terkontaminasi sedemikian rupa untuk mencegah kemungkinan penyebaran penyakit atau kontaminasi”.
Pada prinsipnya, dasar pertimbangan kebijakan lockdown yang secara khusus dibentuk pada kondisi darurat kesehatan harus memperhatikan beberapa komponen fundamental di antaranya: a) Mempunyai relevansi dengan peraturan perundangundangan yang ada. Memperhatikan undang-undang yang sifatnya lebih khusus, berkaitan dengan keadaan darurat dan darurat kesehatan; b) Disusun dengan tetap memperhatikan pada Asas-Asas Umum Pemerintahan Yang Baik (AUPB); c) Mempersiapkan alternatif atas segala kemungkinan yang terjadi atas situasi darurat kesehatan. Sebagai contohnya, ketika dihadapkan pada situasi darurat kesehatan atas virus corona, maka penetapan kebijakan lockdown harus menyiapkan alternatif untuk menanggulangi dampak sosial, ataupun ekonomi yang mungkin terjadi; d) Perlu diperhatikan keseimbangan kepentingan antara pembentuk kebijakan dengan kepentingan masyarakat. Jangan sampai penetapan kebijakan lockdown atas situasi darurat kesehatan, justru hanya menguntungkan dan/atau merugikan pihak tertentu. Apalagi ketika dimunculkan kebijakan lockdown, memunculkan situasi masyarakat untuk menyiapkan kebutuhan logistik; e) Secara substansi, kebijakan lockdown atas situasi darurat kesehatan, harus diikuti dengan menetapkan hak dan kewajiban, baik bagi pemerintah maupun masyarakat. Artinya, ada hak-hak yang diterima oleh masyarakat, misalnya dalam hal pelayanan kesehatan. Tetap juga harus memperhatikan aspek Hak Asasi Manusia (HAM). Apalagi pada saat pelaksanaan kebijakan lockdown, segala bentuk aktivitas masyarakat juga sangat dibatasi; f) Perlu juga diperhatikan berkaitan dengan tingkat risiko atau dampak kesehatan bagi masyarakat. Dilakukan apabila terdapat suatu bahaya atau risiko yang sangat tinggi bagi kesehatan masyarakat, dan sudah terjadi penyebaran virus (diseases) secara masif.

Keenam komponen fundamental tersebut dapat diringkas menjadi beberapa aspek dasar, yang bersifat yuridis, 
sosiologis, ekonomi, bahkan aspek filosofisnya. Hal tersebut menjadi satu kesatuan (kumulatif), dalam perumusan kebijakannya. Menetapkan kebijakan lockdown, yang secara khusus pada situasi darurat kesehatan merupakan bentuk upaya terakhir. Tidak setiap situasi darurat selalu dikeluarkan kebijakan karantina (lockdown), sebab terdapat dampak yang luar biasa terhadap kebijakan lockdown, khususnya aspek ekonomi, pendidikan dan sosial. Pemerintah sebagai pembuat kebijakan, harus mampu secara bijak menetapkan langkah yang tepat dalam menghadapi segala situasi, khususnya jika dihadapkan pada situasi darurat kesehatan. Perumusannya juga harus tetap dilakukan dengan nalar yang sehat, baik yang berpengaruh secara nasional, maupun khususnya pada lingkup daerah (provinsi, kabupaten/kota).

\section{Kebijakan Lockdown atas Situasi Darurat Kesehatan oleh Pemerintah Daerah}

Sebagaimana telah disampaikan bahwa telah terdapat pembagian urusan kewenangan antara Pemerintah Pusat dengan Pemerintah Daerah, dengan didasarkan pada UU No. 23 Tahun 2014. Berdasar pada hal itu pula, maka daerah (Provinsi, Kabupaten/Kota), mempunyai hak otonomi (kebebasan) untuk mengatur daerahnya masing-masing. Daerah juga dapat menyusun produk hukum sendiri, yang berlaku mengikat khusus pada daerah tersebut dalam bentuk Peraturan Daerah (Perda). Meskipun tiap daerah mempunyai kebebasan untuk mengatur urusan rumah tangga daerahnya, dalam konteks hubungan antara Pemerintah Pusat dan Pemerintah Daerah, tetap diperlukan adanya bentuk pembinaan dan pengawasan. Namun, pengawasan yang dilakukan tersebut harus dilakukan secara berimbang. Apabila bentuk pengawasan yang dilakukan oleh Pemerintah Pusat terlalu ketat, maka justru akan membelenggu adanya desentralisasi dan otonomi (Manan, 1994). Ditunjang pula dengan penerapan sistem rumah tangga daerah yang berisifat nyata. Hal ini bertujuan untuk melakukan sinergi, agar pencapaian tujuan sebagaimana yang dituangkan dalam pembukaan UUD NRI 1945, dapat tercapai.

Berdasar pada dasar kewenangan itu pula, pada Pasal 11 dan 12 UU No. 23 Tahun 2014 telah ditegaskan, bahwa salah satu urusan kewenangan wajib daerah adalah berkaitan dengan kesehatan. Dapat dipahami pula, daerah (Provinsi maupun Kabupaten/Kota), mempunyai hak untuk mengelola urusan kesehatan, mulai dari menentukan standar pemenuhan kesehatan, pengawasan, hingga pada penanganan kesehatan masyarakat. Lebih lanjut, berkaitan dengan urusan kesehatan, telah diatur pula pada bagian lampiran UU No. 23 Tahun 2014, yaitu "Pembagian Urusan Pemerintahan Bidang Kesehatan".

Apabila ditelaah lebih lanjut dalam UU No. 23 Tahun 2014, memang tidak terdapat ketentuan yang secara khusus mengatur peran daerah dalam hal wilayahnya mengalami situasi darurat kesehatan. Namun, dalam penanganan kasus bidang kesehatan, dapat ditafsirkan melalui peran pengelolaan kesehatan oleh daerah, termasuk penyediaan tenaga kesehatan dan fasilitas kesehatan. Ketentuan yang demikian itu, dalam kerangka otonomi dan desentralisasi, memang dapat menimbulkan dualisme penafsiran. Pertama, dalam hal situasi darurat kesehatan, Pemerintah Daerah dapat menentukan sikap atau langkah untuk menanggulangi penyebaran suatu wabah penyakit, tidak menutup kemungkinan untuk menetapkan kebijakan lockdown. Hal tersebut didasarkan pada dasar kewenangan yang dimiliki oleh daerah dalam urusan kesehatan, dan suatu kondisi yang tidak kondusif di daerahnya. Apalagi jika lingkup daerahnya hanya pada daerah Kabupaten/Kota, dan diperlukan penanganan dan sikap tanggap dari Pemerintah Daerah-nya.

Kedua, dengan adanya ketentuan lampiran dalam UU No. 23 Tahun 2014, yang telah membagi urusan bidang kesehatan antara Pemerintah Pusat, 
Pemerintah Daerah Provinsi, dan Pemerintah Daerah Kabupaten/Kota, maka terdapat penafsiran sempit jika daerah hanya sebatas melakukan penanganan dalam hal perawatan, pemberian obat, ataupun rujukan di suatu rumah sakit. Pemerintah Daerah tidak dapat menetapkan kebijakan lockdown jika mengalami darurat kesehatan, termasuk pada lingkup daerah Kabupaten/Kota.

Secara normatif, jika turut berpegang pada Pasal 4 ayat (1), 12 dan 22 UUD NRI 1945, maka tafsir kedua itulah yang paling tepat. Pemerintah Daerah tidak dapat menetapkan kebijakan lockdown atas situasi darurat kesehatan di daerahnya. Dipahami bahwa kekuasaan pemerintahan yang ada di daerah adalah turunan dari kekuasaan Pemerintah sebagaimana yang ditegaskan pada Pasal 4 ayat (1), bahwa: "Presiden Republik Indonesia memegang kekuasaan pemerintahan menurut Undang-Undang Dasar". Hal ini juga berarti bahwa pelaksanaan urusan pemerintahan yang ada di daerah, turut berada dalam pengawasan pusat dan harus dilaksanakan sesuai dengan ketentuan peraturan perundang-undangan. Harus dipahami pula bahwa kekuasaan tertinggi tetap berada di tangan Pemerintah Pusat. Hal ini pula yang menjadi dasar bahwa setiap tindakan dari Pemerintah Daerah, pada akhirnya akan dievaluasi oleh Pemerintah Pusat. Aspek krusial yang ditetapkan oleh Pemerintah Daerah, khususnya melalui pembentukan kebijakan, dan dapat berpengaruh bagi masyarakat di luar dari pada daerah tertentu, menjadi bagian penting dari peran Pemerintah Pusat sebagai pemegang kekuasaan tertinggi (Michael, 2016).

Selain itu, hanya Presiden yang dapat menentukan keadaan bahaya, sebagaimana ditegaskan pada Pasal 12 UUD NRI 1945 bahwa: "Presiden menyatakan keadaan bahaya, syarat-syarat dan akibatnya keadaan bahaya ditetapkan dengan undang-undang”. Keadaan bahaya yang dimaksud juga termasuk kondisi darurat kesehatan, misalnya dalam penyebaran wabah virus corona.
Kondisi demikian itu juga sejalan dengan yang diatur dalam UU No. 6 Tahun 2018. Ditegaskan pada Pasal 5, bahwa: "Pemerintah Pusat bertanggung jawab menyelenggarakan kekarantinaan di pintu masuk dan di wilayah secara terpadu". Dilanjutkan pula pada Pasal 10 ayat (1), (2) dan (3), bahwa: (1) Pemerintah Pusat menetapkan dan mencabut Kedaruratan Kesehatan Masyarakat; (2) Pemerintah Pusat menetapkan dan mencabut penetapan Pintu Masuk dan/atau wilayah di dalam negeri yang Terjangkit Kedaruratan Kesehatan Masyarakat; (3) Sebelum menetapkan Kedaruratan Kesehatan Masyarakat, Pemerintah Pusat terlebih dahulu menetapkan jenis penyakit dan faktor risiko yang dapat menimbulkan Kedaruratan Kesehatan Masyarakat.

Berdasar pada ketentuan tersebut, maka semakin memperkuat dasar jika Pemerintah Daerah tidak dapat menetapkan kebijakan lockdown atas kondisi darurat kesehatan dalam lingkup daerahnya, tanpa adanya keputusan dari Pemerintah Pusat. Pemerintah Daerah hanya membantu sesuai dengan arahan Pemerintah Pusat, seperti misalnya yang ditegaskan pada Pasal 55 UU No. 6 Tahun 2018, bahwa: (1) Selama dalam Karantina Wilayah, kebutuhan hidup dasar orang dan makanan hewan ternak yang berada di wilayah karantina menjadi tanggung jawab Pemerintah Pusat; (2) Tanggung jawab Pemerintah Pusat dalam penyelenggaraan Karantina Wilayah sebagaimana dimaksud pada ayat (1) dilakukan dengan melibatkan Pemerintah Daerah dan pihak yang terkait.

Namun, jika ditelaah lebih lanjut khususnya didasarkan pada hak otonomi yang melekat pada daerah, maka hendaknya ada suatu ketentuan yang dapat menjadi dasar bagi Pemerintah Daerah untuk memberikan pengajuan atau rekomendasi kepada Pemerintah Pusat mengenai adanya darurat kesehatan di suatu daerah tertentu. Hal ini bertujuan untuk lebih memberikan perlindungan bagi warga masyarakat, khususnya yang berada di daerah terdampak. Pengaturan dalam UU No. 23 Tahun 2014, 
maupun UU No. 6 Tahun 2018, keduanya sama-sama tidak memberikan dasar kewenangan ataupun peran bagi Pemerintah Daerah untuk (setidaknya) memberikan pengajuan kepada Pemerintah Pusat untuk mengeluarkan kebijakan lockdown jika terjadi darurat kesehatan. Selama ini, Pemerintah Daerah hanya menunggu keputusan dari Pemerintah Pusat. Padahal, suatu kondisi darurat kesehatan memperlukan penanganan yang cepat dan tanggap, khususnya terhadap suatu virus yang dianggap berbahaya seperti virus corona. Meskipun diketahui pula bahwa dalam menetapkan suatu peraturan kebijakan lockdown bagi negara atau wilayah tertentu, diperlukan suatu kajian yang komprehensif agar tidak berdampak merugikan bagi masyarakatnya.

Pada kondisi seperti inilah hubungan koordinasi antara Pemerintah Pusat dengan Pemerintah Daerah (Provinsi, Kabupaten/Kota), harus disinergikan. Teringat pula akan suatu adagium, "tidaklah timbul kekacauan atas suatu kaum di muka Bumi, melainkan hingga datangnya suatu wabah/penyakit". Pemerintah sebagai fasilitator haruslah mampu bertindak secara progresif, yaitu menitikberatkan pada tujuan dan nilai kemanfaatannya, dari pada sekedar melihat pada prosedur. Aspek progresif ini juga turut mempertimbangkan logika keadilan. Esensi dari hukum, bahwa "hukum untuk manusia" harus dikuatkan, dengan mengingat hukum untuk manusia (Rahardjo, 2006). Artinya, demi memberikan kemanfaatan yang lebih bagi masyarakat, dan dengan mendasarkan pula pada nilai keadilan, progresivisme ini berani mendobrak langkah prosedural yang dianggap memperlambat arah pengembangan hukum, khususnya ketika hukum diperlukan di waktu krusial dalam menyelesaiakan persoalan kemanusiaan. Namun, tentunya tetap harus melihat pada kesesuaian peraturan perundang-undangan yang ada (Mukhidin, 2014).

Nilai dasar dari hukum progresif yang digagas oleh Satjipto Rahardjo, mempunyai relevansi dalam penyusunan kebijakan lockdown di suatu daerah. Mengesampingkan prosedural yang justru menghambat tindakan cepat yang seharusnya dilakukan oleh Pemerintah, khususnya dalam menghadapi darurat kesehatan di tingkat Daerah (Provinsi maupun Kabupaten/Kota). Hal ini juga mengingat bahwa eksistensi hukum seharusnya mampu untuk mencegah dan mengatasi persoalan yang timbul di masyarakat, bukan menghambat penyelesaiannya (Faizal, 2016). Secara tegas, dengan berdasar pada hak otonomi, dan hukum progresif, serta peraturan terkait dengan kewajiban daerah dalam bidang kesehatan, maka idealnya Pemerintah Daerah dapat membentuk kebijakan lockdown tanpa harus menunggu keputusan dari Pemerintah Pusat yang sifatnya prosedural. Apalagi jika di suatu daerah tersebut sudah mengalami situasi yang kritis dan genting. Mekanisme prosedural yang terlalu positivistik justru menghambat penanganan situasi darurat kesehatan.

\section{Simpulan}

Dasar fundamental penyusunan kebijakan lockdown atas situasi darurat kesehatan dengan memperhatikan aspek yuridis, sosiologis, ekonomi bahkan filosofisnya. Aspek yuridis dengan melihat pada kesesuaian peraturan perundangundangan, dan asas-asas yang berlaku. Aspek sosiologis dan ekonomi dengan melihat pada urgensi di masyarakat, dan pertimbangan ekonomi, termasuk menentukan langkah alternatif atas dampak yang timbul. Filosofisnya memperhatikan tujuan dasar pembentukan kebijakan, termasuk dengan memperhatikan hak-hak masyarakat. Menyesuaikan pada dasar tersebut, maka di tingkat daerah (Provinsi maupun Kabupaten/Kota), sangat mungkin dilakukan lockdown atas situasi darurat kesehatan. Untuk saat ini, dengan berdasar pada peraturan perundang-undangan yang ada, memang Pemerintah Daerah tidak dapat menetapkan kebijakan lockdown tanpa adanya Keputusan dari Pemerintah Pusat. Namun, berdasar pada hak otonomi, dan 
hukum progresif, serta tanggungjawab Pemerintah Daerah dalam bidang kesehatan, maka idealnya daerah dapat menyusun kebijakan lockdown tanpa harus menunggu keputusan Pemerintah Pusat. Apalagi jika Daerah yang bersangkutan sedang dalam situasi kritis dan menghendaki tindakan segera.

\section{DAFTAR PUSTAKA}

Adhari, A. (2019). Ambiguitas Pengaturan Keadaan Bahaya Dalam Sistem Ketatanegaraan Indonesia. Dialogia Iuridica: Jurnal Hukum Bisnis Dan Investasi, 11(1), 43-61.

Amaluddin. (2020). Dishub Jatim Beri Kelonggaran Akses Masyarakat di Surabaya Raya. Medcom.Id. https://www.medcom.id/nasional/daerah $/ 1 \mathrm{KYxPoQk-dishub-jatim-beri-}$ kelonggaran-akses-masyarakat-disurabaya-raya

Asshiddiqie, J. (2007). Hukum Tata Negara Darurat. Rajawali Pers.

Baihaki, R. (2020). Anomali Instruksi Presiden dalam Penanganan Wabah Corona.

https://news.detik.com/kolom/d4942778/anomali-instruksi-presidendalam-penanganan-wabah-corona

Basah, S. (1992). Perlindungan Hukum atas Sikap Tindak Administrasi Negara. Alumni.

Budiardjo, M. (2008). Dasar - Dasar Ilmu Politik. Gramedia Pustaka Utama.

Faizal, L. (2016). Problematika Hukum Progresif di Indonesia. Ijtima 'iyya, 9(2).

Hadjon, P. M. (2005). Pengantar Hukum Administrasi Indonesia. Gajah Mada University Press.
Hamidi, J. (1999). Penerapan Asas-Asas Umum Penyelenggaraan Pemerintahan yang Layak (AAUPB) di Lingkungan Peradilan Administrasi Indonesia. Citra Aditya Bakti.

HR, R. (2010). Hukum Administrasi Negara. Rajawali Pers.

Mahfud, S. M. dan M. (1987). Pokok-Pokok Hukum Administrasi Negara. Liberty.

Manan, B. (1994). Hubuungan Antara Pusat dan Daerah Menurut UUD 1945. Pustaka Sinar Harapan.

Mukhidin. (2014). Hukum Progresif Sebagai Solusi Hukum yang Mensejahterakan Rakyat. Jurnal Pembaruan Hukum, 1(3), 267-286.

Nuh, M. S. (2011). Hakekat Keadaan Darurat Negara (State Of Emergency) sebagai Dasar Pembentukan Peraturan Pemerintah Pengganti Undang-Undang. JURNAL HUKUM, 18(2), 229-246.

Pangerang, A., \& Pradana;, S. A. (2018). Pokok-Pokok Hukum Pemerintahan Daerah. Rajawali Pers.

Rahardjo, S. (2006). Membedah Hukum Progresif. Kompas.

Sheeran, S. P. (2013). Reconceptualizing States of Emergency under International Human Rights Law: Theory, Legal Doctrine, and Politics. Michigan Journal of International Law, 34(3), 491-557.

Simamora, J. (2010). Multitafsir Pengertian "Ihwal Kegentingan yang Memaksa" dalam Penerbitan Perppu. Mimbar Hukum - Fakultas Hukum Universitas Gadjah Mada, 22(1), 58-70. https://doi.org/10.20303/jmh.v22i1.300 